\title{
Colonial Desire and the Renaming of History in Richard Flanagan's Wanting
}

Salhia Ben-Messahel

\section{(2) OpenEdition \\ 1 Journals}

Electronic version

URL: https://journals.openedition.org/ces/5269

DOI: $10.4000 /$ ces.5269

ISSN: 2534-6695

Publisher

SEPC (Société d'études des pays du Commonwealth)

\section{Printed version}

Date of publication: 1 September 2013

Number of pages: 21-32

ISSN: 2270-0633

\section{Electronic reference}

Salhia Ben-Messahel, "Colonial Desire and the Renaming of History in Richard Flanagan's Wanting", Commonwealth Essays and Studies [Online], 36.1 | 2013, Online since 16 April 2021, connection on 22 July 2021. URL: http://journals.openedition.org/ces/5269 ; DOI: https://doi.org/10.4000/ces.5269

\section{(c) (†) $\odot$}

Commonwealth Essays and Studies is licensed under a Licence Creative Commons Attribution - Pas d'Utilisation Commerciale - Pas de Modification 4.0 International. 


\section{Colonial Desire and the Renaming of History in Richard Flanagan's Wanting}

In Wanting (2009), Australian novelist Richard Flanagan examines the tragic outcome, physical violence and psychological disfigurement brought about by colonisation. The main story is set in Victorian England and colonial Tasmania, places that encapsulate the voices of the silenced others. In his interrogation of the colonial past and individual desire, Flanagan probes the interconnections between civilisation and savagery, colonialism and postcolonialism, fiction and reality, and in so doing reconfigures and renames history by exposing the wanting elements in colonial discourse.

The process of naming and labelling has been an important feature of the exploration and exploitation of land and territories by man. It became central to the appropriation of place and the imposition of European and imperial culture during colonisation in the eighteenth and nineteenth centuries. Australia, as a British colonial outpost, was not spared by the process of naming in the same way that the British colonies in the Americas or in the South Pacific were given British names to mark the extension of the Empire and the emergence, from a colonial point of view, of new and Europeanised places. The labelling of Australia as Terra Nullius by the British authorities suggested that the land belonged to no one and that Britain was entitled to it all, especially as it was not exploited by Indigenous people in a European way since the latter did not use the land for agricultural and industrial development. The legal doctrine of Terra Nullius consequently justified Britain's appropriation of place and Eurocentric approach of naming and renaming at a time when the Western world endeavoured to conquer what was thought to be untamed and uninhabited territories, for the grandeur of empires and to "civilize the savage." Thus, after the arrival of the first British fleet on Australian shores, the newly discovered continent took various names and labels: "Terra Australis," "New Holland," "Great South Land," "the colony" and "penal settlement," for political and geographical designs. Paul Carter in his celebrated work The Road to Botany Bay insists that names invent the spatial and conceptual co-ordinates within which history occurs, that they bring history into being and embody the existential necessity a traveller feels to invent a place s/he can inhabit (Carter 46-7). The Commonwealth of Australia, or merely "Australia" in the twenty-first century, still bears different names, some inherited from the past, and others which are either new creations or colloquialisms and which encapsulate the nation's sense of difference from Europe and the sense of belonging to the southern hemisphere: "Down Under" or "OZ," the latter often taken by outsiders to Australia as an oblique reference to the fictional Land of Oz. Indeed, the Australian territory has always been used as the backdrop of various histories and stories, and it is a fact that European writers wrote fictional accounts of an imagined Great Southern Land long before British settlement in Australia. In 1642, Abel Janszoon Tasman, the Dutch explorer who landed in what is now the state of Tasmania, imagined that giants peopled the newly discovered land. His speculation would later inspire Jonathan Swift to place the land of the Houyhnhnms in Gulliver's Travels in the Western part of the island (Case 50-68). Located in the state of Tasmania, also known as Van Diemen's Land, 
Wanting (2008) by Richard Flanagan is a tale of two islands, Britain and Tasmania. The background to Flanagan's novel is Victorian England and colonial Australia during the time of the British conquest in isolated and new territories, but the story also extends to Britain's quest for the Northwest Passage in the Arctic and Britain's perception of the Arctic as an exclusively British space.

In his novel, Flanagan uses the historical fate of Jane and John Franklin in Australia and the latter's expedition in the Arctic as well as the history of Mathinna, an Indigenous girl, intertwining such stories with the story of Charles Dickens. In 1854 Lady Jane Franklin, then widow of Sir John Franklin, the polar explorer, met Charles Dickens, urging him to refute a recent article about her husband's disappearance in the Arctic some nine years earlier and the rumours that Franklin's crew had resorted to cannibalism to survive. Dickens, who had just completed his celebrated novel Hard Times and who was about to start writing Little Dorrit, was outraged at the slur on this hero of the British Empire and endeavoured to counterattack in his own magazine, Household Words. Dickens's defence of Sir John Franklin appears as a near-racist tract claiming that it was physically and morally impossible for brave, civilized white men to descend to the level of savages.

In the novel, Charles Dickens, the most famous novelist and triumphant thespian of Britain in the nineteenth century, features as one of the main characters sharing the story with Mathinna, a young Tasmanian Aboriginal girl, one of the abused natives, doomed to be civilised, adopted and then abandoned by Sir John Franklin, the famous explorer and governor of Tasmania, and his wife, Lady Jane. In the novel the naming and renaming of place and people is a potent demonstration of the ways in which the power of discourse may operate, and the labelling process may extend to the question of literary genre. In the postface to the novel, Flanagan asserts that his novel "is not a history" and "nor should it be read as one" (255). He insists that the "stories of Mathinna and Dickens, with their odd but undeniable connection, suggested a meditation on desire the cost of its denial, the centrality and force of its powers in human affairs. [...] That, and not history," he adds, "is the true subject of Wanting" (256). Flanagan's claim is that his purpose is to explore the nature of want at the heart of human experience in colonial times. Such an exploration was previously carried out in his other novels, for instance Death of a River Guide (1997) and Gould's Book of Fish (2002). In both novels as well as in Wanting, Tasmania's history is used as a means of interrogating the effect that desire has on mankind, and as a means to show that the characters' personal story often entails reason, expanding on the fallacies of rationalism and utopianism in colonial times. Wanting nonetheless raises questions about the use and rewriting of history in a post-colonial context. One might indeed wonder whether Flanagan's insistence on individual feelings in the context of the colonisation of Australia and Britain's Victorian Age is not an attempt to represent history in a postmodern mode, and thus avoid the criticism levelled at authors such as Kate Grenville on the publication of her historical novel $A$ Secret River (2005) for her description of indigenous-settler relations. Flanagan often dismisses in fact the importance of the Empire and the Commonwealth, arguing that he, just like a number of Australians, does not feel concerned about the "dream of Empire" and "its shadow, the Commonwealth," adding that the multicultural nature of Australia can no longer sustain the memory of the past and the Empire. He argues that the history of the Empire is an oddity, and that Australians belong to a vast and trou- 
bled country (Flanagan, My Commonwealth). In Gould's Book of Fish, Flanagan tackles the complex relationship between facts and fiction in regard to history and identity, and he pursues this interest in Wanting, which also deals with history in order to examine how individuals attempt to create their own subjectivities while establishing a relationship between their selves and history. The examination of history as representation rests upon a process of deconstruction common to postcolonial writing, so that both history and the characters' desires are shifting and constantly questioned or renamed. Thus the reader may wonder whether the dynamic of renaming revolves around the rewriting of history and the denunciation of the colonial past under the guise of personal desire, a desire for the wanting elements to be exposed as the title of the novel suggests. Is Wanting playing with the historical fiction genre by including historical characters to design new histories? Is the author's ability to deploy discursive strategies a means to dismiss the imposition of the British past on the Australian cultural map? How does the interplay of fiction and history construct a postmodern and postcolonial story about human want and the devastating effects of reason or rationalism?

The novelist's claim that the novel is not historiography but rather a reflexion on desire, want (and greed) is sustained by the epigraph to the novel, lines from Fyodor Dostoevsky's novel, Notes from Underground:

You see, reason, gentlemen, is a fine thing, that is unquestionable, but reason is only reason and satisfies only man's reasoning capacity, while wanting is a manifestation of the whole of life. (n.p.)

The epigraph, by putting in perspective reason (the intellect) and want (the senses), suggests that wanting prevails over reason since human needs can never be satisfied. It illustrates the central idea in Flanagan's novel that individuals are motivated by many contradictory impulses.

The opening pages of the novel are told by a character, "the Protector," who gives an overview of a time of colonisation and strife for both "the Empire" and "France" (1-3). The character's thoughts establish a distinction between the way he perceives the colonised in the British colonies and in the French colony in Algeria. Britain has to deal with "tame" or "wild" blacks, or tribes, whereas France is confronted with a rebel with a proper name: "Abd al-Qadir" (3). The Protector's view refers to the idea that the two empires differed in their definition of "colonisation": the British believed their colonised subjects were essentially different from Europeans and that this would always be the case - a point of view that relied on racism, implying, in the case of Australia, that Indigenous people were not just different but also inferior - while the French argued that they were prepared to treat their colonial subjects as equal to French citizens if they assimilated. Thus the categorisation of otherness by the Protector defines the Indigenous Australian as an inferior being while the Algerian resistance fighter seems to be a respected figure (the man who in fact dares defy Britain's imperial rival), whose actions are ironically associated to great events that took place at the same time in Britain: "It was 1839. The first photograph of a man was taken. Abd al-Qadir declared a jihad against the French, and Charles Dickens was rising to greater fame with a novel called Oliver Twist" (3).

Set during the colonisation of Van Diemen's Land, one of the furthermost outposts of the British Empire, which sheltered Australia's most brutal penal settlements, the story is told through an orientalist discourse of otherness based on racism and 
primitivism. The "othering" of the blacks and their description as inferior people depends upon what Abdul JanMohamed calls "the Manichean allegory" in which a binary and implacable discursive opposition is produced (60) that consequently suggests that the mental projection of the indigenous as a commodity is essential to the legitimate construction of the insider, seen as the "white self." Alternatively called the "preacher" and "Protector of indigenous people," the character first sees his mission as a "friendly mission" (57). He ponders on the Van Diemonian tribes who resist colonial rule with hardly any means other than a fierce determination to maintain their culture and keep their land:

Those who saw them said it was hard to believe that such a small and wretched bunch could have defied the might of the Empire for so long, that they could have survived the pitiless extermination, that they could have been the instruments of such fear and terror. It wasn't clear what the preacher had said to the blacks, or what the blacks thought he was going to do with them, but they seemed amenable, if somewhat sad, as broken party after broken party were embarked on boat after boat and taken to a distant island that lay in the hundreds of miles of sea that separated Van Diemen's Land from the Australian mainland. Here the preacher took on the official title of Protector and a salary of $f, 500$ a year, along with a small garrison of soldiers and a Catechist, and set about raising his stable charges to the level of English civilisation. (1-2)

The character's various names encapsulate his dual attitude towards Indigenous people. He is a figure of Janus: as a preacher, he is on an evangelical mission to help build a colony of settlement "where the colonisers seize the land, introduce their own labour force and destroy the economic and cultural basis of pre-existing Indigenous societies," but as a Protector he takes part in the formation of the colony of exploitation "in which the ruling colonial elite concentrates on the extraction of economic value from the natural and human resources of the country" (Gothard et al 10). The character re-enacts the common colonial practice of distinguishing between people regarded as "untamed" and those who are constructed as natives, dispossessed of their land but pertaining to a territory owned by the Empire. The Protector, like the Franklins, considers that it is his duty to raise the blacks to white standards and to control them by christening and renaming them, but again his "friendly mission" (57) also implies that the Indigenous people must respond to the fantasy of conversion and the ideology of a Victorian age marked by new moral and intellectual values. The Protector's encounter and discussion with Lady Jane Franklin point to the scientific racism (theories of race and racial classification) common to the colonial era. Scientific progress, which marked the embodiment of an age that never ceased to look forward to a new period characterised by convictions and firm beliefs, emphasised racial discrimination and cultural regression so that discussions of race, rather than challenging negative stereotypes of savagery and inferiority, tended to emphasise them:

Lady Jane had declared the Van Diemonian Aborigines there a scientific curiosity as remarkable as the quagga roaming free in the Ménagerie du Jardin des Plantes. And so the vice-regal party now found itself sitting down to dinner in the Protector's cottage, while listening to the Protector's grand - and it had to be said - rather lengthy tales of his historic mission of conciliation. (56)

Lady Jane resorts to the animal imagery reminiscent of eighteenth- and nineteenthcentury perceptions of the savage as a sub-human deviant other who is the antithesis of Europe and civilisation, an imagery that relies on exoticism and negates the subject. 
The Franklins' scheme of destruction and salvation in Tasmania reflects the phobias and responses to otherness that lie at the heart of imperialism. History is approached in a way that recalls Foucault's statement that:

The human being no longer has any history: or rather, since he speaks, works, and lives, he finds himself interwoven in his own being with histories that are neither subordinate to him nor homogeneous with him. [...] the man who appears at the beginning of the nineteenth century is "dehistoricized." (402)

Flanagan's perspective lends itself to a psychoanalytical and anthropological reading in that he probes the uncanny and the unconscious of history to show that imperialism was created on the basis of positive narratives of progress and civilisation and negative stereotypes such as laziness, deceit and irrationality. Wanting consequently operates as a grand narrative of nineteenth-century historicism relying on evangelism and evolutionism: concepts essential to colonial and imperialist governance. Like their Victorian fellows, the Franklins evolve between two worlds, one dead or dying, one struggling to be born, where everything was held to be open to question and where individuals "seemed to themselves to be living in a house built on unshakable foundations and established in perpetuity ... the Home, the Constitution, the Empire, the Christian religion - each of these ... was accepted as a final revelation" (Houghton 10, ellipses in original).

The adoption of Mathinna by the Franklins with the blessing of the Protector is justified by Lady Jane's wish to fulfil her desire to be a mother but also by her belief that it is her duty to raise the black girl with every advantage of class and rank, "for science and for God" (69). The formation of Mathinna's new colonial identity as part of the Franklins' grand design in the Australian antipodes is marked by her subsequent acculturation and fall. Such a pattern is suggested in the way the various metaphoric descriptions of the girl unfold and expose various stages in her psychological development. Mathinna is viewed as a "savage pet" (51) before she turns into the exotic princess entertaining her white audience (53) and becomes an "empty black vessel" (135) until the end when she dies, alone and destitute, at the age of seventeen, "half-hyena and fully a princess, queer, lost, belonging and not belonging" (251). The character, by acquiring Western culture and mastering the language of the coloniser, is able to fit in with the mainstream but is nonetheless regarded as the cultural other that will never be fully assimilated. The character's development shows the capacity of colonial control to bind the colonised into a binary myth of civilisation and acculturation, being and notbeing, resistance and submission. As Bill Ashcroft notes in his discussion of imperial discourse, colonial control is responsible for the inevitable absorption of the colonised into the colonial myth of force and/or myth of nurture:

Underlying all colonial discourse is a binary of colonized/colonizer, civilized/uncivilized, white/black, which works to justify the mission civilisatrice and perpetuates a cultural distinction which is essential to the "business" of economic and political exploitation. The idea that "counterforce" is the best response to the colonialist myth of force, or to the myth of nurture, both of which underlie this civilizing mission, binds the colonized into the myth. This has often implicated colonized groups and individuals in a strategy of resistance, which has been unable to resist absorption into the myth of power, whatever the outcome of their political opposition. (21)

In the novel, the colony of Tasmania is described through the colonial perception of the settlers and ruling parties. The Franklins embody the colonial establishment and 
colonial control of space; they are literally described as royalty in their newly acquired kingdom. Sir John Franklin and Lady Jane clearly epitomise the British establishment and morals in a place that evokes a romantic enchantment to some idealists, explorers or artists, while it is perceived by the colonial ruling power as a bare and harsh territory to be tamed. The colony rests upon a duality between the awesome and the gruesome; it is viewed either as "an absurd, upside down, bastard imitation of England" (58), or through an idealised vision stemming from Greek mythology (103-4).

Colonial culture, with its dual and complex perception of the Australian colony, is also often put in perspective with Indigenous Dreamtime, through Mathinna's oneness with the land and her totemic bond with the native animals. The interaction of Western and non-Western myths and stories is clearly encapsulated in Mathinna's original name "Leda," given by the Protector. The name alludes to the mythological story of Leda, wife of King Tyndareus of Sparta and daughter of Aetolian King Thestius, who was raped by Zeus when he came to her as a swan, but it also suggests, from an Indigenous perspective, the spirit being of the Dreamtime who symbolizes death for Mathinna. Such references are signified in the recurrent imagery of the black swan as an omen marking the young girl's spiritual and physical death after she is possessed, exhibited like a wild animal and then raped by Sir John Franklin (151-2).

In the novel, the naming process not only designates or distinguishes the character or a referent but also brings to the fore what is not explicitly expressed so that the characters or the narrator can be positioned socially and discursively. Names often lay emphasis on the binaries of displacement/acculturation and identity/being. Thus, it is ironic that Dickens himself should associate names with the appropriation of place and history: “'Greatness like Sir John's comes but once in an age,' he said, seeking to wrench his fancy from these terrible visions. 'A Magellan, a Columbus, a Franklin - they do not vanish, neither from the earth nor from history"' (24). It is just as ironic and subversive that the grand scheme of sending expeditions to the South Pole should be symbolised by the sending of ships whose names explicitly refer to darkness and chaos:

Lady Jane spoke of the 2 splendid ships, the Terror and the Erebus returned from their epic Antarctic voyage and fitted out with the most modern engineering marvels: steam engines and retractable screw propellers, copper sheathing, even a steam-powered organ that could automatically play popular tunes. (22)

The narrator's ironic stance does not merely subvert the character's belief in the grand design of the imperial voyages but also seems to contest the dominant and Eurocentric understanding of history by Lady Jane and her society. Moreover, the plot rests upon a simultaneous construction and deconstruction of history that is performed through the demythologising of canonical figures and a parallel between the two main characters, Dickens and Mathinna. The novel starts for instance with the death of Dickens's baby-girl, Dora, and the surfacing of Mathinna, King Romeo's young daughter, as a main character. The experiences of both characters work contrapuntally on the issue of desire and the consequences of denial, sketching the dominant and discursive paradigm: the control structure of personal or political power in colonial Australia and Victorian England. From the very beginning, Mathinna is depicted as the substitute "daughter" of the Franklins as much as Catherine Dickens herself realises that she has become Dickens's invention "as surely as any of the blurred pages on the desk, as much as any of those dull creatures he passed off as women in his books" (159). Dickens, just like the 
Franklins (and later on Mathinna), is affected by desire rather than reason; his attraction for Ellen Ternnan subverts his initial claim that the civilised man does not succumb to his natural instincts, considering that he is unable to resist his attraction and sexual desire for the girl (156).

All characters ironically become the puppets of their desires, desires that are finally sacrificed for reason and social conventions, and that reveal their own inability to fully be their true selves. Looking at his reflection in a mirror, Charles Dickens sees "a face that could have been any man and no man, somebody who in his relentless mimicry of everybody had become nobody" (93). Sir John Franklin often surfaces as an absence or a negative space while Mathinna, after she had "enjoyed" being immersed in white civilisation and being courted by Sir John Franklin in the most ridiculous and tragic dancescene (139-40), is sadly found dead on a muddy track (250). The character's relation to white civilisation is ambiguous considering that she is eager to be accepted by her foster parents and to be integrated in white society but at the same time is invariably drawn back to her cultural roots and Indigenous spirituality. Throughout the novel, Mathinna's voice can be interpreted as a counter-discourse to the Franklins' or Charles Dickens's beliefs and statements - just as Dickens's development seems to stand counter-discursively against imperial culture - so that the bond between coloniser and colonised is creative for the coloniser, who feels that educating the native is a charitable and political mission, but destructive for the colonised, who gradually becomes an acculturated subject and lost soul:

Sometimes, as she lay alone in those two large rooms that were hers, so alone in an emptiness that felt to her greater than the starry night, she tried to unravel her many fathers. It was like the catechism: it made sense if you repeated it enough and didn't ask questions. There was God her father, and Jesus his Son, who was also a sort of a father; and there was the Protector, who had the Spirit of God the Father; and then there was Sir John, who was also her father, her new father - so many fathers. (120)

By embracing the culture of the Mother Country, an act that is symbolised in the novel by a red dress, Mathinna fulfils the coloniser's dream of educating the savage. She becomes the centre of attention, which she at first enjoys, wishing her black skin to be washed white and remaining blind to her enslavement until the very end of the novel. She is consumed by desire and her dream of rising up in settler society as the assimilated subject even though she still recalls her life with her Indigenous relatives and Indigenous culture. Mathinna's desire exceeds any kind of reason when she is exposed at a masquerade ball as the Franklins' possession and wild pet:

They walked up the gangplank and on to the Erebus's upper deck, which for that night was to be the ballroom [...]. From the corner of her eye she could see others adjusting themselves, with a rustle here and a sigh there, in front of a large mirror at the landing that led up to the foredeck. Around her floated compliments, bitter asides, meaningless words.

"Our princess of the wilds!" sighed a wolf.

All week she had practiced the quadrille.

"The sweetest savage!" said a bear. [...]

In the midst of the dance's lively finale, Mathinna realised she was no longer holding Sir John's hands nor in step with anyone else, as she had so patiently practiced, but was moving to something more fundamental and deep-rooted than a dance invented fifteen years ago in Paris. (149-50) 
Mathinna's eagerness to be part of white society gradually triggers the Franklins' feeling of awe and hatred for cultural otherness, and shows that while she is enslaved by her inferiority and willingness to be assimilated as a white (and superior) being, the Franklins are enslaved by their feeling of superiority to such an extent that they can never fully accept their adopted daughter as their own. Mathinna ironically demonstrates the equation probed by $\mathrm{H}$. K. Bhabha in The Location of Culture, that "it is always in relation to the place of the Other that colonial desire is articulated: the phantasmic space of possession that no one subject can singly or fixedly occupy, and therefore permits the dream of the inversion of roles" (44).

The novel shows that the colonised and the coloniser are inextricably linked however distinct they may appear at first. When the novel was released Flanagan insisted on the deliberate association between Mathinna's story and Dickens's:

I realise that these stories of an unknown Aboriginal girl at the end of the world and the most famous man of his age were in fact one, two poles of the same globe. What joined them wasn't just an odd series of connected events but something deep within the human heart with which we've always struggled and continue to struggle with, and that is this endless battle between desire and disciplining desire and reason and wanting. (Flanagan in Koval 4)

Flanagan's novel seems to be part of a new trend in the postcolonial novel whereby the story is not necessarily framed as a journey into a brutal history, or even as an instance of the former empire "writing back" to a centre, but as a display of multiple viewpoints and effects so that power and representation are still the fuel of postcolonial theory but have simply ceased to operate as its core matter. Wanting examines the past and the imperial vision from a postcolonial perspective whereby it involves a recognition of historical, political and social circumstances, but the novel can also be viewed as a postmodern story, which by rewriting the local story of Mathinna, Charles Dickens, the Franklins, contests the dominant Eurocentric interpretation of history. Thus, the depiction of Mathinna as one of the main characters allows the Indigenous voice to stand in a counter-discursive relation to the imperial and settler culture just as Australia's convict-culture and settler-culture stand counter-discursively against imperial culture:

She stopped trapping birds. She drank more. It was apparent to her - albeit in a dull and confused way that she found beyond any words she knew either of her own tongue of English - that other people seemed to revel and delight with purpose in this life and this world. Ma'am existed for a reason, for hundreds of reasons with names like Education, Advancement, Civilisation. The convicts longed to escape, the soldiers to become settlers, the settlers to make money. Even the old people at Oyster Cove held the hope to return to the land and the ancestors, if not in this life then in the next. (230)

By juxtaposing Van Diemen's Land with London and Manchester in the middle of the nineteenth century, the story constructs complex ironies about a paradise lost (or destroyed) and the dark, satanic factories that are the accomplices of material progress in the industrial era. Dickens's sentimentalist view recurrently surfaces through his theatrical staging of The Frozen Deep, a play written with his friend Wilkie Collins and inspired by Sir John Franklin's polar expedition and fate in the Arctic. Britain's conception of the Arctic as British space relied on the romantic belief that exploration was part of the British spirit of enterprise. The Arctic exploration is used as the background of the play in which Dickens acts as a central character. It is a space which Dickens poetically sees as a new page of history to be written: "The case was building, and he was now feeling 
words rushing from his goose-quill along, leaving trails of ink, blue as ice, leading him and his readers to that strange and terrible world" (42).

Dickens often wonders if names such as "talent" and "genius" are just words marking his own determination to expose himself literally on stage (93) when he realises that he feels something beyond reason, a blind desire for Ellen Ternnan. His attraction for the young actress revolves around an open sensuality, physicality, and so-called irrational tendencies usually attributed to the savage:

And at that moment Dickens knew he loved her. He could no longer discipline his undisciplined heart. And he, a man who had spent a life believing that giving in to desire was the mark of a savage, realised he could no longer deny wanting. (241)

In the novel, the experience of dispossession and dislocation, which is both psychic and social, associates racism and colonisation with individual narcissism and want rather than with the politics of nationalism. By alternating Dickens's inner voice with the voice of a narrator, the narration recalls the dual narrative of the Dickensian novel where the narrator is free to comment on a character, in this case Dickens (or even Wilkie Collins who, according to the narrator, is living in the shadow of Dickens). The narrator is thus able to discuss Dickens's link to Wilkie Collins and to anticipate a future reality:

Wilkie Collins' nerves were still good; he was yet to invent the detective novel, to be celebrated by his age as one of the great novelists and thereafter forgotten, to have his health fail, to take so much opium to ward off the pain that he would come to believe he had a doppelgänger, the Ghost Wilkie. The world for Wilkie was a promise yet to fracture into phantoms, his eyes were yet to turn into bags of blood, and the great Dickens was a friend and mentor. (38-9)

The narrator's tone of voice, controlling and omniscient, is a means to act as an intruder and remind the reader that imagination and reality are interdependent. The narrator addresses the reader, wondering about the character of Dickens and mocking the way the novelist seems to forget his criticism of Victorian ideals and pointing out his social hypocrisy:

But what of Dickens? For those who had followed the greatest mystery of the age, the prospect of the most popular writer of the day putting forth his view on the sensations of the rumours of cannibalism was irresistible. [...] Thus did Dickens ally his name with the salving of an empire's anguish, and no one was ungrateful. (71)

The narrative voice, by providing a view from above, deconstructs the idea of a linear time and space so that the characters' inner reality can be fully exposed and history openly subverted. The narrator criticises Victorian society for its inability to acknowledge that Dickens disregarded historical facts to save the reputation of John Franklin, and also shows how Dickens uses elements from his reality for his own stories, suggesting that fiction suddenly takes on a life of its own to surface in the writer's reality. The development of the story gradually demythologises Dickens's canonical status, shedding light on his disbelief in the noble savage (29), his scathing attacks against colonised people and his scientific racism: "A savage, my dear Wilkie, be he Esquimau or an Otaheitian, is someone who succumbs to his passions. An Englishman understands his passions in order to master them to powerful effect"' (83).

Dickens's eagerness to take over Wilkie Collins's allegorical play, The Frozen Deep, by acting as the character of Robert Wardour, the self-sacrificing hero in the Arctic expedition, shows the extent to which literary and poetic discourse can become a political tool 
in the service of power and a "glorious English history," (143) and serves two objectives. The first is to assert his claim that the Franklin expedition in the Arctic, in 1845, did not resort to cannibalism, and to distort the historical facts gathered by the Scottish explorer, John Rae, that the Franklin expedition did indeed resort to cannibalism; the second is to allow him to view fiction as reality so that he can act out his imagined life and fantasy on stage and thus let go of his repressed and unconventional feelings for a young actress. Dickens, by endorsing the name and character of Robert Wardour, is consequently able to play out the life he wants under the guise of a fictitious character, in other words a fantasised other, in the same way that the narrator has authorial command under the guise of fiction. The shifts from Dickens's stream of consciousness to the narrator's comments seem to suggest that fiction and reality are interchangeable, and that history is an illusory space. The narrator is free to fill in the gaps for the reader, just as Flanagan imagines and rewrites the destiny of the Franklins, Mathinna and Dickens. Bill Ashcroft's argument that both history and fiction are language games deployed in different contexts is consequently true for Flanagan's novel, which collapses the binaries history/fiction or truth/untruth, and thus deploys a method that emphasises the provisional nature of history rather than simply doing away with it (Ashcroft 136). Flanagan transposes historical facts into fiction by insisting on the importance of aesthetic form, on the way the story is put into shape and on the form of its telling rather than only on its narrative content. In the tradition of nineteenth-century fiction, Flanagan's novel depicts Victorian England's secret attraction to allegedly savage non-Western cultures, even as Europe claimed superiority over them, and addresses the issue of individual desire in order to look at the tenuous link between civilisation and savagery, good and evil. Yet in so doing, the story opens up a space for interrogation that subverts man's eternal desire for fixity of identity and authority. Charles Dickens enters the life of Robert Wardour in the same way that the narrator, and in the process the reader and the novelist, enter the life of the characters through the recreation of reality and fictionalising of history. Unlike a biographer or historian, the narrator and the novelist are not in that case constrained by documented facts nor by missing elements, they are free to proceed beyond the space of history through character and motive, supposition and possibility, to create a world where flat and conformist portraits of individuals become rich and three-dimensional, where characters such as Mathinna can surface and become active participants in a new history to provide a view on what Flanagan calls "the catastrophe of colonialism," and where Tasmania's colonial past and secrets are exposed. Wanting interrogates the nature and motives of individuals but also resonates with the idea that:

With the Aborigines written out, the Australian story seems apolitical, a faintly heroic tale of white man against Nature, of "national achievement" devoid of blacks, women and other complicating factors. With the Aborigines in it, the story is completely different. It is a story of theft, dispossession and warfare, of massacre and resistance. It is a story every bit as rapacious as that of the US, Spanish America, and Colonial Africa and Asia. It is, above all, a political story. (Pilger 31)

Mathinna's experience remains a tragic episode in the history of colonisation and can be read, to that extent, as history revisited by fiction. Yet, the juxtaposition of real events and characters (or even the cross-bordering of characters such as Robinson and King Romeo, first encountered in Gould's Book of Fish) with fiction creates ambiguity and challenges the legitimacy of history. 
By addressing human want at a particular time in the history of Britain and in the history of Australia, Richard Flanagan designs discourses that operate simultaneously and independently so that his "non-historical" novel indicates that Australian history is not an extension of British history, but a reflection of a history resting upon want and greed. The story does not manifest a resistance to Britain but a resistance to post-colonialism, which engages with the culture and history of the colonising power. Flanagan's assertion that Wanting is not about history but about individual desire is true, but his novel proposes a dual narrative which is both postcolonial and postmodern, and which suggests that history can never entirely be defined. The overlapping of postcolonial and postmodern approaches sustains a dialogue with the past that, on one hand, involves recognition of historical, political and social circumstances but, on the other, grants value to the margins of the other - the wanting elements that are hinted at in the novel's title and which in fact refer to the missing truth that the colonisation of Australia, under the guise of progress, led to the misery and denial of the Indigenous peoples. Wanting generates a discourse that questions and redefines issues of identity, individual aspirations and cultural otherness, and thus reconfigures and renames history. The novel advocates a passive resistance which sympathises with the oppressed rather than achieves structural change, which examines the power of want over politics and history, which engages both reader and author in an endless debate about Australia's cultural identity and Australia's destiny as a nation in a global environment. Flanagan invents a fictionalised history of human want and the (personal and political) power derived from it so that history is conceived as the story of human histories in nineteenth-century England (the imperial centre) and Australia (the subaltern nation). The reconfiguration of history suggests that culture must be liberated from the destructive dialectic of imperial history and that imagination is the key to this. Wanting constructs a story of the past that is free of the assumptions of the master narrative of British history and operates as history revisited and renamed from an "antipodean" perspective - a history that can never be fully written and assessed.

Salhia BEN-MESSAHEL University Charles-de-Gaulle Lille 3

\section{Works Cited}

Ashcroft, Bill. Post-Colonial Transformation. London: Routledge, 2001.

CARTER, Paul. The Road to Botany Bay. London: Faber, 1987.

Bнавна, Homi K. The Location of Culture. London: Routledge, 1994.

CASE, Arthur E. Four Essays on Gulliver's Travels. Princeton: Princeton UP, 1945.

Flanagan, Richard. Death of a River Guide. Sydney: McPhee Gribble, 1994.

-. Gould's Book of Fish. Sydney: Picador, 2001.

—. "My Commonwealth 'A Ghostly Memory of a Master Race'." The Guardian. 19 July 2002.

—. Wanting. London: Atlantic Books, 2009.

Foucault, Michel. The Order of Things: An Archeology of the Human Sciences. Trans. Alan Sheridan. New York: Random, 1970.

Gothard, Jan, Laksiri Jayasuriya, and David Walker, eds. Legacies of White Australia. Crawley: U of Western Australia P, 2003.

Grenville, Kate. The Secret River. Melbourne: Text Publishing, 2005.

Houghton, Walter. The Victorian Frame of Mind 1830-1870. 1957. New Haven: Yale UP, 1985.

JanMohamed, Abdul. "The Economy of Manichean Allegory: The Function of Racial Difference in Colonialist Discourse." Critical Inquiry 12 (1985): 59-87. 
Koval, Ramona. "Wanting: Richard Flanagan Interview." The Bookshow. ABC Radio transcript. 12 November $2008<$ http://www.abc.net.au/radionational/programs/bookshow/wanting-richard flanagan/3179486>.

Pilger, John. A Secret Country. London: Vintage, 1990.

SwIFT, Jonathan. Gulliver's Travels. 1726. Oxford: World's Classics, 2008. 